\title{
The revolution in local government: mayors in Portugal before and after 1974
}

\author{
MARIA ANTÓNIA PIRES DE ALMEIDA*
}

ABSTRACT. In 1974, Portugal's Carnation Revolution, initiated by the military, received huge popular support. Army officers, mostly of the rank of captain, started the Revolution, but then the politicians took over. While it was largely a 'top down' revolution, at the local government level ordinary people assumed control. In this article we consider those who made up the local elites before the Revolution, during the transition period that followed, and thereafter. We compare the local elites in Portugal during Salazar's dictatorship with those under the Democratic regime, using a database of 6,000 entries containing details of 3,102 mayors and deputy mayors and 402 civil governors who held office between 1936 and 2013. Our main conclusions are that during the transition period the elite who had ruled under Salazar were almost completely replaced. A new group, from different professions and social backgrounds, took up the reins of local government. The Revolution produced a population willing to participate in the new order and take on roles within local government, but they did not always retain their seats after the first democratic elections.

\section{INTRODUCTION}

On 28 May 1926 a coup d'état ended the First Portuguese Republic, which had been established on 5 October 1910. A military dictatorship was then enforced until a new constitution was approved in 1933 and a new regime, known as 'the New State', was established, headed by António de Oliveira Salazar as President of the Council of Ministers. Salazar led the country until 1968 when, after falling off a chair, he was replaced by Marcelo Caetano, who ruled the country until the New State was ended in 1974 by the Carnation Revolution (so called because on the day of the revolution no bullets were fired and instead flowers were placed in the soldiers' guns).

\footnotetext{
* CIES - Centre for Research and Studies in Sociology, ISCTE, University Institute of Lisbon.
} 
The New State was a corporatist, authoritarian regime, highly centralised and dictatorial. That it lasted for four decades was mainly due to Salazar's capacity to integrate the country's elites into the new corporative institutions, such as local associations of farmers called 'grémios', which coordinated each region's economic activities, combined with support from the Catholic Church, social repression and a strong secret service. ${ }^{1}$ Also, as in most authoritarian regimes, 'coercion remain[ed] the core feature of [dictatorship], and fear, violence, intimidation and surveillance [was] at the core of political domination and of the maintenance of authoritarianism'. ${ }^{2}$ The military, industrialists, landowners and bankers all benefited from state protection and found themselves in charge of the principal corporative institutions in each sector of the country's economy.

The authoritarian policies were also reflected in local government. Since medieval times Portuguese local councils have had a tradition of autonomy and self-government, with local elites holding power in areas where central government could not reach. ${ }^{3}$ This changed with the arrival of the New State and its centralised government through which the regime tried to control every aspect of daily life, creating corporative institutions for every section of the economy and society, affecting power relations at the local level. We were interested to see whether the old, local elites were replaced, or whether the same families controlled local affairs under the New State.

When a new, democratic regime was established after the Revolution in 1974 everything changed again. The Revolution was led by the Armed Forces Movement (Movimento das Forças Armadas) or MFA, which assumed responsibility for the Revolution and the initial phase of the post-revolutionary period (Período Revolucionário em Curso) or PREC. Not only did the institutional and legal framework change under the new regime, particularly with the introduction of democratic elections, but municipalities also gained a new constitutional right to more autonomy from central government, particularly regarding political choices and financial management. We wished to investigate whether this transition from one regime to another also modified the way in which local elites were recruited and selected.

In considering the transitions from one regime to another we must ask several questions: who held local power, determined policy and headed institutions in Portugal? Which social and occupational groups controlled town councils under the New State, during the 1974-1976 transition, and after the first democratic local elections held on 12 December 1976? How did the characteristics of council mayors evolve, and did the criteria for holding office change as one regime gave way to another?

To answer these questions, a great deal of data was collected from institutional sources, such as official government journals, municipal and district archives, the national election committee and, for mayors elected after 2009, 
the press and municipal and government websites. This led to the creation of a database with more than 6,000 entries referring to 3,102 mayors and deputy mayors, including those nominated to be chairmen or members of the administrative committees who ran local government during the transition period immediately after the Revolution, as well as the 402 civil governors elected between 1936 and 2013 in the 18 districts of mainland Portugal and the four island districts covered by the current regional governments of Madeira and the Azores. There were 304 municipalities in 1974, but since 2001 there have been 308 . The database, which was constructed on a prosopographical basis, ${ }^{4}$ holds the names and ages of each individual as well as the dates on which they were appointed and left office, the length of the terms they served, their educational attainment, occupation and social and family background. It also contains details of each individual's political careers before and after they took office. ${ }^{5}$ Using this information our analysis sought to characterise the elite groups running local government in three significant time periods in Portuguese history, that is, during the New State, the 1974-1976 transition, and the democratic period established by the Democratic Constitution of 1976 and the introduction of regular elections, in order to detect continuities and changes in the methods of, and criteria for, recruitment to these elites. In addition, differences and similarities between elite groups in various regional settings - in the north and south, on the coast or inland, in urban versus rural areas - were considered, along with the political and spatial mobility of those leading local government. This analysis demonstrated the impact that the transition from a dictatorship to a democracy had on the careers and lives of those in local government who were, for the bulk of the population, the most accessible representatives of the state. Over the course of the changes in regime those holding elite positions in local government were replaced, even though there was some continuity in the groups represented, the recruitment criteria applied, and the elements that determined access to the these positions. Today, post-materialist values among the youngest generation in post-industrial societies have led to the gradual erosion of class-based politics, ${ }^{6}$ and class and ideology are no longer the main factors shaping local government in Portugal. These traditional criteria appear to have been superseded by such factors as the candidate's personality and his or her direct contact with the electorate.

Portuguese historiography traditionally presents studies of local elites in monographs considering particular localities. They often refer to the distant past, in order to extol the long-lasting social or political importance of publicly recognised figures from that locality. Over recent decades, however, academics have developed a new interdisciplinary approach to such local studies. Their theories and methodologies, drawn from across the humanities and social sciences, have helped to construct portraits of local societies that yield a previously untapped level of understanding. ${ }^{7}$ 
By studying local political elites throughout Portugal, when considering the impact of the transition to democracy, we hoped to gain a more rigorous and accurate understanding of this elite group, which both represented local populations and mediated between them and the central powers, and thus formed the boundary between society and the state. ${ }^{8}$ As the role of local government evolved over the transition to democracy, its nature changed and it is of historical interest to analyse how the changes affected the individuals involved. In this article we compare the sociological characteristics of those in local government with those of the political elites of the New State and Democratic Period, including central government ministers, members of parliament and Presidents of the Republic.

As in many other European countries, one significant way in which the political landscape in Portugal changed over the twentieth century was the much greater participation of women. In Portugal, Carolina Beatriz Ângelo, a medical doctor, widow and mother, was the first woman to vote. She did so in the election for the 1911 National Assembly, which went on to produce the Constitution of the First Republic. Invoking her status as head of her family, Ângelo secured a court order granting her the right to vote, but the law was quickly changed in response and Portuguese women were denied the franchise until 1931 when they were given the vote for the first time. Even then the franchise was limited to female heads of families or women with a secondary school certificate or a university degree, while men only had to be able to read, write and count to vote. Between 1934 and 1973 only 14 women were elected to the National Assembly or to the Corporate Chamber, the upper and lower chambers of the Portuguese parliament. Several of the women were elected to leading roles within the corporative institutions of the New State, such as the Mocidade Portuguesa (MP - Portuguese Youth), the Obra das Mães pela Educação Nacional (OMEN - Mothers for National Education) and the Instituto Maternal (IM - Mothers' Institute). ${ }^{9}$ One woman was appointed Under-Secretary of State for Social Assistance in 1971.

As Portugal made the transition to democracy, a 1974 law established that both sexes were to have complete equality as electors for the first time; other laws also ushered in civic, social and political equality. The year 1974 also saw women chairing for the first time the administrative committees that ran the town councils, and on 16 May that year Maria de Lourdes Pintasilgo was the first woman to be appointed to a government position. Initially she took up the post of Secretary of State for Social Security in the first Provisional Government, before becoming Minister of Social Affairs in the Second and Third Provisional Governments from July 1974 to March 1975. In 1979 she became Portugal's first, and so far only, female prime minister. From the first democratic elections in 1976 onwards a growing number of women were elected both to parliament and to the town councils, and later 
as members of the European parliament. Although a number of women have been appointed to government office, and there is no formal discrimination between the sexes, it remains the case in Portugal, as in the most other countries, that there is 'under-representation of women in positions of political authority'. ${ }^{10}$

2. THE LEGAL AND POLITICAL FRAMEWORK OF PORTUGUESE LOCAL GOVERNMENT DURING THE TWENTIETH CENTURY

The organisation of local power in Portugal is a legacy of liberalism. In 1835 administrative reform created the position of the Civil Governor, the head of each of the 17 districts in mainland Portugal and 4 more in the islands of Madeira and Azores. Incumbents were responsible for organising the election of members of parliament and for handing down laws, regulations and orders from the government to subordinate layers, such as municipalities and parishes. In the early twentieth century the Republic recognised that, following a number of reforms during the nineteenth century, the country's then 18 districts were well embedded into the organic structure of the state and that the civil governors had evolved into important delegates of central power.

The coup d'état on 28 May 1926 led to the suspension of the existing administrative arrangements. In the following July the corps of administrators for the mainland and island districts were abolished, leaving the civil governors responsible for nominating citizens to become members of the administrative committee of any town council to the Interior Ministry. From that point on the civil governors represented the power of central government. The administrative committees operated between 1926 and December 1937, when they were dissolved and mayors were appointed to run the town councils. In this way the New State assimilated the old elites into the cadres of local government, just as the Republic had assimilated the local elites of the previous monarchy.

The administrative reform carried out during the New State was largely contained within the Administrative Code prepared by Marcelo Caetano, which enshrined the principle of local authority. The code was approved in 1936 and reviewed in 1940 to introduce some changes. Under the code each civil governor was held to be the government's representative with an important role in the administration of his district, as he controlled the activities of the mayors who were to be appointed by the Interior Ministry on his recommendation. Throughout the New State regime the councils were almost entirely politically and financially dependent on central government.

According to the Administrative Code, town councils were to consist of a mayor plus a variable number of councillors. Mayors were to serve terms of six years but could be appointed for more than one term. In 1940 the 
Administrative Code extended terms to eight years, largely because it had been proven difficult to find people willing to take the position of mayor, particularly in the interior of the country, as the post holder was expected to be suitably qualified, take on a demanding role and, in most cases, receive no remuneration in return. For instance, Vila do Bispo, a small village in the Faro district, Algarve, Portugal's southernmost region, had no mayor at all for much of 1964. Faro's civil governor did not like Vila do Bispo's local priest, the main candidate for mayor, and wanted to appoint an army lieutenant who used to go there for his summer vacations. The lieutenant did not accept the post, arguing that it would be too expensive to move to the locality, leaving his family in Lisbon. Another lieutenant was appointed, after he was promised financial assistance, and he remained in post until 1973. ${ }^{11}$

Mayors were chosen from among local dignitaries; representatives of the most prestigious social and economic groups who possessed social capital, such as academic qualifications or personal or family status within the local community, ${ }^{12}$ or economic capital. As the position of mayor could not be undertaken alongside any other state-funded public duties, mayors had to have the means to support themselves, and be able to continue these activities while undertaking their administrative and law enforcement duties. They had no financial or political autonomy, as most decisions had to be approved by the civil governor and the Minister of the Interior.

The process for selecting mayors and their councils evolved during the twentieth century. During the monarchy and the First Republic councillors and mayors were elected; during the New State mayors were appointed by the Ministry of Interior upon the civil governor's suggestion; and from 1976 they were once again elected, this time by the whole population. During the periods of transition, from 1926 to 1937 and from 1974 to 1976, town councils were run by administrative committees appointed directly by the Ministry of the Interior.

On 25 April 1974, the day of the Carnation Revolution, those in the most senior state positions; the President of the Republic Américo Tomás; the head of the Portuguese government Marcelo Caetano; all the ministers and secretaries of state and the Members of the National Assembly, the Upper Parliament, were all dismissed under Law No. 1/74. The same day all civil governors were dismissed by Government Decree No. 170/74. Mayors were allowed to stay in office until the Minister for Internal Administration was given the authority to dismiss the old administrative bodies and replace them with administrative committees 'made up of independents or people belonging to groups and political currents that accept the MFA Programme'. ${ }^{13}$ The newly-appointed administrative committees remained in office until the first local elections on 12 December 1976. Until the administrative committee responsible for a particular town council was appointed, the 
old council was expected to work under the direction of the 'most senior' councillor, but never the old mayor. On 2 May 1974 the Diário do Governo, the official government journal, began to publish ministerial orders (portarias) dismissing those mayors who remained in office. The government announced that the terms of all mayors would come to a close on 18 June 1974. Naturally, where a mayor did not 'identify' with the MFA Programme, or where they felt under local political pressure, they presented their resignations before this deadline. For the next two years the local authorities were again managed by administrative committees; the new regime had almost entirely replaced the local political elites.

The civil governors' powers and range of actions were reduced by the Democratic regime, until these posts were abolished in 2011. Following a general trend in Western countries during the 1960s and 1970s, a process of administrative decentralisation and strengthening of local power has been underway in Portugal since 1974, with 'traditional' reforms being carried out to strengthen the political and administrative institutions of the social state. ${ }^{14}$ The country's 1976 constitution made it clear that politicians favoured decentralisation, as citizens were given a wider array of rights and opportunities, including a greater ability to influence and participate in local decisionmaking processes. The constitution also laid out the roles and responsibilities of government in the municipalities, parishes and administrative regions, indicating that local governments were to have political, legislative and financial autonomy. This did not in fact transpire; even today local government in Portugal remains dependent on central government for most of its finances and some authors have argued that decentralisation was never completed, leaving the country a centralised and bureaucratic state. ${ }^{15}$ Today the locally elected representatives in Portugal's municipalities consist of a mayor and a group of councillors with executive powers who control their own revenues. They are overseen by a municipal assembly, but local autonomy has become a reality, particularly with regard to budgetary, management and construction issues. This autonomy has, however, led to a number of financial problems, including municipal debts and cases of corruption.

Since 1976 there have been regular local elections in Portugal. Until 1985 these were held every three years, but since then they have been held every four. Political parties were introduced into the democratic regime and into people's habits of political representation, after over half a century without them during the military dictatorship and the authoritarian regime. The constitution proposed a party list proportional representation system as the best way to ensure that every political party was represented on a council, no matter which party won the majority of votes. For this to work each party had to create a network of local organisations and find supporters within the local communities. In this way, it was believed, the population would learn the 
unfamiliar habits of political representation. The political parties would act as schools for local democracy.

Portugal's political system continued in this form until a revision of Article 239 of the constitution in 1997 allowed community groups to present candidates in local elections. This revision was passed with little discussion, as it was seen as the natural next step within a stable democracy, but a proposal to allow such candidates to stand in parliamentary elections was rejected. Independent candidates had been allowed to stand in parliamentary and local elections by the 1976 constitution, but only if they were included in the list of a political party's candidates along with a statement that they were standing as an independent. Community groups had been able to contest parish council elections since 1976, but the 2001 elections were the first to accept candidates for town councils standing under their own name or as part of a group with no connection to any registered political party. Such groups were similar to the 'local parties' seen in northern European countries such as Germany, Belgium and in Scandinavia. These countries have federal regimes that show strong commitment to the main political parties at central and regional government level, but no such commitment at the lower municipal level where political organisation is consequently much more laissez faire. ${ }^{16}$ There is no evidence of this trend in Portugal, where the political parties remain the dominant force in local government ${ }^{17}$ and at the heart of every other level of politics. ${ }^{18}$ Even though 13 independent mayors were elected in 2013, 4.2 per cent of the country's total, the parties continue to control a majority of the electoral process in Portugal. ${ }^{19}$

\section{MAYORS UNDER THE NEW STATE, 1936-1974}

The Portuguese New State had a strong central government but a weak civil society. The few individuals making up the social and administrative elite were very well educated. Members of parliament and ministers were specialists in their own fields; most were university professors. Salazar himself held a $\mathrm{PhD}$ and was a full professor of Political Economy and Finance at the age of 29. It is little wonder the New State was referred to as the 'Empire of the Professor'. ${ }^{20}$

At the local government level, and particularly in remote rural areas, it was difficult to find people to fill all the administrative and political posts, as few residents met the necessary criteria. The central government selected a civil governor for each of the 18 districts, who then selected the mayors from among the elite of each local area as a means of assimilating them, and the populations they governed, into the New State, just as the Republic had done in $1910 .{ }^{21}$ Corporative institutions were created to control industry, agriculture, and social services; the central government deliberately did not 
provide the latter. ${ }^{22}$ Members of the local elites, who already provided many of the jobs and services in their regions, took control of the new institutions simply because no one else had the skills and social capital to do so. ${ }^{23}$

At least 58.5 per cent of the mayors appointed at the end of 1937 had led the administrative committees appointed during the transition period between the 1926 coup that ended the Portuguese First Republic and the New State. Between December 1937 and 1974 a total of 1,829 mayors were appointed. The majority were appointed only once; but 95 of them were appointed twice or more, either to the same or to a different council. Among those 95 mayors there was some geographic mobility, generally - but not always within the same district, and associated with the individual's professional mobility. On average a mayor served for 5.3 years; the longest serving was in post for 21.3 years.

During the New State almost 35 per cent of mayors were drawn from 'specialist' occupations (the National Occupational Classification refers to intellectuals and scientists as 'specialists') (Table 1). 'Military Officers' accounted for a further 22 per cent. Of the officers appointed or elected as mayors between 1937 and 2013, 91 per cent took up their post before 1974, and 48 per cent of these men were retired. There were many cases, particularly in rural municipalities, of officers retiring from their military careers, returning home and taking on the post of mayor. Mayors who were also serving military officers tended to be found in municipalities that included a strategic defence position, an army or navy college, or a barracks. In Oeiras, near Lisbon, Don João António de Saldanha Oliveira e Sousa was both an earl - although this title had no legal standing under the Republic - and a high-ranking army officer serving in Oeiras' Artillery Regiment. Because of his family's tradition of public service, and their political support of the new regime, Don João António was appointed as president of Oeiras' administrative committee in 1933, and then became mayor in 1937. Remembered for promoting important construction works such as the local school, sewer system and water supply, he was one of the longest serving mayors in Portugal, as he remained in post until $1957 .{ }^{24}$

Lisbon, the Portuguese capital, had a long tradition of appointing highranking military officers as its mayor, but from 1937 to 1943 the job was given to Duarte Pacheco, an engineer and university professor, who combined the role of mayor with the position of Minister of Public Works, just as the city underwent a series of major construction works. On the other hand, in Porto, the second city, the majority of mayors during the New State were civilian; only one retired infantry colonel sat as mayor, his term in office running from 1949 to $1953 .{ }^{25}$

There does not appear to have been a deliberate policy of placing military officers in local, municipal government. The position of mayor did not carry 
TABLE 1

The occupations followed by mayors during the New State, 1937-1974

\begin{tabular}{lrr}
\hline \hline & $\begin{array}{c}\text { Number of } \\
\text { mayors }\end{array}$ & $\%$ \\
\hline Farmers & 12 & 1.36 \\
Bankers & 1 & 0.11 \\
Merchants & 13 & 1.47 \\
Entrepreneurs/Industrialists & 28 & 3.16 \\
Specialists - intellectuals and scientists (medical doctors, engineers & 307 & 34.69 \\
and others) & & \\
Civil Servants & 52 & 5.88 \\
Nobles & 11 & 1.24 \\
Military Officers & 195 & 22.03 \\
Priests & 45 & 5.08 \\
Administrative and Similar Personnel, Services and Salesmen & 1 & 0.11 \\
Teachers & 124 & 14.01 \\
Landowners & 61 & 6.89 \\
Senior Managers and Directors in Public Administration and & 24 & 2.71 \\
Business & & \\
Technicians and Intermediate-level Professionals & 11 & 1.24 \\
Total Occupations & 885 & 100.00 \\
\hline \hline
\end{tabular}

Source: Decrees and ministerial orders appointing mayors and Civil Governors, 1937-76, published in the government journal Diário do Governo / Diário da República.

great political importance; it was largely an administrative job and military officers, doctors and engineers were all nominated because they were usually the most qualified persons to serve in this capacity in their municipality. Civil governors were a different matter, however; as their power was delegated from the central government, and for the duration of the New State military officers were placed in strategic districts, making up 30 per cent of all appointed civil governors.

It was easier to glean information on mayors' educational qualifications than it was to discover their occupations, because the term 'Dr', which implies a university degree, appears in their appointment decrees. With this information we may infer that the great majority were university educated; of those appointed during the New State only 7.1 per cent did not have a university qualification (Table 2). All the ministers and 86.7 per cent of the members of parliament in post between 1968 and 1974 had university degrees. ${ }^{26}$ In comparison, 40.3 per cent of the Portuguese people in 1960 could neither read nor write and only 0.6 per cent had a university degree, although this figure rose to 4.9 per cent in 1994 and 22.9 per cent in 2011 . Their educational qualifications thus mark politicians out as an elite group. ${ }^{27}$ 
TABLE 2

The educational qualifications of mayors during the New State, 1937-1974

\begin{tabular}{lcc}
\hline \hline Level of educational qualification attained & Number of mayors & $\%$ \\
\hline No formal education & 1 & 0.07 \\
Primary school & 2 & 0.14 \\
Fifth year of secondary school (present ninth year) & 3 & 0.22 \\
Technical course & 17 & 1.22 \\
Secondary school & 8 & 0.57 \\
Baccalaureate & 26 & 1.87 \\
Higher studies & 569 & 40.85 \\
Undergraduate degree & 676 & 48.53 \\
Primary teacher & 68 & 4.88 \\
Postgraduate degree & 8 & 0.57 \\
PhD & 15 & 1.08 \\
Total & 1393 & 100.00 \\
\hline \hline
\end{tabular}

Source: See Table 1.

The New State and its political staff grew old. Salazar was Minister of Finance and then President of the Council when he was in his early thirties. The ministers in his first cabinet were mostly young professors and professionals, such as Duarte Pacheco, who was appointed Minister of Public Education when he was 28 years old and Minister of Public Works when he was 32. This contrasted with Salazar's successor Marcelo Caetano, who was 62 when he was appointed in 1968. In the final five years of the New State, 1969-1974, ministers were, on average, 50 years old and members of the Portuguese parliament $49 .^{28}$

Between 1936 and 1974 the average age of newly appointed mayors was 45.2 years. The process of ageing was not so apparent in this group; mayors appointed in the early years of the New State were 44.2 years old, on average, in its final years they were 46.8 (Table 3).

4. POWER OF THE PEOPLE AND LOCAL POWER: THE TOWN COUNCIL

ADMINISTRATIVE COMMITTEES DURING THE REVOLUTIONARY PERIOD,

$$
1974-1976
$$

In 1974 Portugal's citizens organised themselves into administrative committees and assumed control of the political transition, managing the councils until the first local government elections were held on 12 December 1976. The transition period that followed 25 April 1974 saw the development of new local elites and the social re-composition of a large number of councils, 
TABLE 3

The average age of mayors during the New State, 1937-1974

\begin{tabular}{lc}
\hline \hline Dates & Average age of mayors (years) \\
\hline $1937-1950$ & 44.2 \\
$1951-1960$ & 46.6 \\
$1961-1974$ & 46.8 \\
\hline \hline
\end{tabular}

Source: See Table 1.

with a much greater diversity of occupations among the councillors (Table 4). Nevertheless there were some communities where the political leadership, and the criteria for inclusion in this group, did not change.

The transition period was marked by widespread instability at all levels of society. 'The power lay in the streets' ('O Poder Caiu na Rua'), and popular action sometimes took a violent turn. ${ }^{29}$ The municipal authorities were not immune, and some former representatives of local power found themselves in danger. Generally, however, the transition of power between the old and the new councils was peaceful. The role of the Armed Forces Movement (the MFA) in the transition should be noted, particularly its Cultural Empowerment Campaign and the 'enlightenment' sessions that it conducted in rural areas. ${ }^{30}$ Through these initiatives the MFA sought to help the people take control of the new political situation, as well as broadcast the Communist Party programme. Meeting with the people directly, the representatives of the MFA encouraged them to create the conditions necessary for political organisation at the village level. From October 1974 the MFA began to publish a journal: The 25 th April Movement: Bulletin of the Armed Forces, which was distributed free to those in the military, encouraging them to motivate the people to engage with the revolution, self government and, for those in the south of Portugal, agrarian reform. ${ }^{31}$ Through their various campaigns the MFA were able to denounce the 'fascist' and 'dictatorial' legacy of the past. The campaigns also made some military units very influential at the local level and boosted the people's morale. ${ }^{32}$

The MFA was particularly active in ensuring that the laws that ended private companies and the expropriation of land were followed, creating a path towards a soviet-based economy. On 25 November 1974 the Third Provisional Government issued Decree No. 660/74 regarding economic sabotage, and which allowed government intervention in the management of companies considered to be working below their potential production levels. ${ }^{33}$ This law provided the legal framework of the Revolution and encouraged a 


\section{TABLE 4}

The occupations of Administrative Council Chairmen, 1974-1976

\begin{tabular}{|c|c|c|c|c|c|c|}
\hline Occupation & $\begin{array}{c}N \\
\text { Males }\end{array}$ & $\begin{array}{c}\% \\
\text { Males }\end{array}$ & $\begin{array}{c}N \\
\text { Females }\end{array}$ & $\begin{array}{c}\% \\
\text { Females }\end{array}$ & $\begin{array}{l}N \text { Males } \\
\quad \text { and } \\
\text { Females }\end{array}$ & $\begin{array}{l}\% \text { Males } \\
\text { and } \\
\text { Females }\end{array}$ \\
\hline $\begin{array}{l}\text { Specialists - Intellectuals } \\
\text { and Scientists }\end{array}$ & 147 & 32.3 & 2 & 22.2 & 149 & 32.1 \\
\hline Teachers & 59 & 13.0 & 3 & 33.3 & 62 & 13.4 \\
\hline Merchants & 51 & 11.2 & 0 & 0.0 & 51 & 11.0 \\
\hline Civil Servants & 37 & 8.1 & 2 & 22.2 & 39 & 8.4 \\
\hline $\begin{array}{l}\text { Administrative and Similar } \\
\text { Personnel, Services and } \\
\text { Salesmen }\end{array}$ & 33 & 7.3 & 0 & 0.0 & 33 & 7.1 \\
\hline $\begin{array}{l}\text { Technicians and } \\
\text { Intermediate-level } \\
\text { Professionals }\end{array}$ & 30 & 6.6 & 0 & 0.0 & 30 & 6.5 \\
\hline Entrepreneurs/Industrialists & 23 & 5.1 & 0 & 0.0 & 23 & 5.0 \\
\hline Landowners & 21 & 4.6 & 0 & 0.0 & 21 & 4.5 \\
\hline Bankers & 17 & 3.7 & 0 & 0.0 & 17 & 3.7 \\
\hline Military Officers & 12 & 2.6 & 0 & 0.0 & 12 & 2.6 \\
\hline $\begin{array}{l}\text { Farmers (tenants and small } \\
\text { landowners) }\end{array}$ & 9 & 2.0 & 0 & 0.0 & 9 & 1.9 \\
\hline $\begin{array}{l}\text { Workers, Craftsmen and } \\
\text { Machine Operators }\end{array}$ & 4 & 0.9 & 0 & 0.0 & 4 & 0.9 \\
\hline $\begin{array}{l}\text { Other Military (police } \\
\text { officers and other military } \\
\text { forces) }\end{array}$ & 4 & 0.9 & 0 & 0.0 & 4 & 0.9 \\
\hline Priests & 4 & 0.9 & 0 & 0.0 & 4 & 0.9 \\
\hline Rural Workers & 2 & 0.4 & 0 & 0.0 & 2 & 0.4 \\
\hline Housewives & 0 & 0.0 & 1 & 11.1 & 1 & 0.2 \\
\hline Unemployed & 1 & 0.2 & 0 & 0.0 & 1 & 0.2 \\
\hline Others & 0 & 0.0 & 1 & 11.1 & 1 & 0.2 \\
\hline Not stated & 1 & 0.2 & 0 & 0.0 & 1 & 0.2 \\
\hline Total & 455 & 100.0 & 9 & 100.0 & 464 & 100.0 \\
\hline
\end{tabular}

Source: See Table 1.

policy of nationalisation of the banks, insurance companies, transport and other sectors crucial to the national economy. It also led towards agrarian reform.

In northern Portugal the majority of the population owned only small properties and were largely conservative and devoutly Catholic. This was not a propitious environment for social revolution. In contrast, the southern region of Alentejo, which occupies 41 per cent of Portugal's area, was 
home to just 8 per cent of its population, according to the 1981 census. The large estates (latifundia) that characterised the region were encouraged by both its geography and weather conditions. Agriculture was traditionally undertaken by farmers - both landowners and tenants - who were considered to be the 'rich' in an extremely polarised society, where workers were the 'poor' ${ }^{34}$ By the late sixties the region had already seen considerable social change, thanks to the emigration of workers to Lisbon's industrial belt; to the war fought between 1961 and 1974 in the former Portuguese colonies in Africa (Angola, Guinea-Bissau and Mozambique); to the mechanisation of agriculture; and to the introduction of social security that had helped to increase wages and living conditions in the agricultural areas. ${ }^{35}$ The Revolution and the attempt to introduce soviet-style structures into the Portuguese economy created the perfect scenario for agrarian reform, particularly one in which all large estates were seized. The radical legislation enacted at the end of 1974 gave farm workers the perfect excuse to occupy the land they worked; the communist propaganda produced by the revolution told them they could own their bosses' land, and they believed it. ${ }^{36}$ The movement towards agrarian reform awakened profound echoes of the longstanding struggles, hopes and resentments of the agricultural workers. ${ }^{37}$ Over one million hectares of land in the Alentejo region were expropriated by the state in 1975 and occupied by workers, managed by Collective Production Units, or UCPS, created along soviet lines. Avis, a municipality in the Portalegre district, in the north of Alentejo, saw some 40,666 hectares seized and occupied. It was one of the largest expropriations, which represented 67 per cent of the municipality's total area and 71 per cent of its farmland. ${ }^{38}$

In the end the agrarian reform did not work. There was too much land for the workers' capacity to manage it; too many salaries to pay and too little profit to do so. Neither production nor productivity rose during the euphoric years immediately after the Revolution, despite the claims of the Portuguese Communist Party. On the contrary, according to official statistics, corn production failed to reach the high levels of the 1960s, even though the cornfields had been enlarged. The number of cattle fell; the production of olive oil and wine shrank to practically zero; and cork production, Alentejo's largest source of income, was siphoned off by corrupt industrialists. Local interviews and research on life stories confirm that salaries remained the same after the Revolution as before it. The only advantages that the workers gained were greater job stability and the end of unemployment. Sharecroppers, who had seen their lifestyles improve before the Revolution, had to join co-operatives in order to survive. This was seen as a retrograde step by the sharecroppers who were unhappy at being paid wages, just the same as other workers. When conditions were created to encourage the renting of land again, the sharecroppers were the first to take advantage of the situation. ${ }^{39}$ 
In contrast landowners, tenants and traditional farmers were expelled from the land they had worked. The old economic elites were completely and irreversibly replaced; ${ }^{40}$ the local lords were no longer in charge of the villages they had ruled for centuries. ${ }^{41}$ In the end the agrarian reform was reversed and gradually, between 1978 and the 1990s, land was returned to its previous owners, and compensation paid. On the other hand nationalisation of the banks was not reversed and many bankers actually bought their banks back from the state.

As we have seen, ministerial orders dismissing mayors from the New State were published on 2 May 1974. Between 26 April and 27 May that year, a total of 11 mayors were removed from office. The first to go was the mayor of Barreiro, which was an industrial town on the south bank on the river Tagus, near Lisbon. The rest of Barreiro's council was dissolved shortly thereafter, by a ministerial order dated 15 May, and replaced by an administrative committee formed of a chairman and 18 councillors. This number of councillors was more than 3 times the average number of 4.9 councillors in administrative committees across the rest of the country. Just how absurd this number of councillors was is highlighted when it is realised that the municipality of Barreiro was home to a population one tenth the size of Lisbon's, yet both Lisbon and Porto, Portugal's second city, had only 12 councillors, although Lisbon also had 2 vice-chairmen of the council, and the towns of Braga (an important industrial town in the North of Portugal) and Coimbra (home of one of the oldest universities in Europe, founded in the thirteenth century), had only 6. Barreiro illustrates the degree of political activism evident in certain parts of Portugal. The case attests to the enormous desire of the country's ordinary citizens to participate in the administration of their local region; it also shows that the Interior Ministry was ready to formalise the appointment of individuals nominated by local administrative committees.

By the end of May 1974, a total of 81 mayors had been removed from office; between 3 and 15 June a further 101 mayors were dismissed and when the legal deadline of 18 June was reached, another 109 mayors were automatically removed from their positions. Ten mayors were reconfirmed in their positions before 18 June; three were appointed as chairman of their local administrative committee in 1974 before being elected as mayors in the democratic elections of 1976. These three men, representing around 1 per cent of all mayors, were unusual; in general the transition period between 1974 and 1976 saw notable changes in the social profile of those running local government.

In the written versions of the ministerial orders appointing administrative committees to run the councils in 1974, the occupation of each chairman and councillor was listed, allowing analysis of the changes that occurred during the revolutionary period. These occupational profiles let us reflect on whether particular local areas favoured change or continuity. 
The first administrative committee appointment went against the grain: in Lisbon on 2 May 1974 João António Lopes da Conceição, a Lieutenant Colonel of Engineers, assumed the duties of the former mayor, who had not yet been officially dismissed. Conceição was a member of the National Salvation Junta, the Junta da Salvação Nacional (JSN), the military' force created under the Revolution to support provisional governments until the first elections could be held in 1975. The other members of the administrative committee appointed to run Lisbon city council were not named until 28 August. The group of 12 councillors included several senior highly qualified officers, with expertise in fields of interest to the local authority. António Sarmento Lobato Faria, for instance, was an engineer who studied for a master's degree in public health in London, while José Augusto França, a professor of art history, was made chairman of a new consultative committee charged with the preservation of Lisbon's artistic and urban heritage. While the new administrative committee demonstrated a willingness to renovate Lisbon, stating clearly that they wanted to make services more dynamic and to restructure the city's sanitation, as well as improving working conditions, the members of the committee had professional backgrounds very similar to those of the previous elite council, such as high-ranking military officers and engineers.

By 8 July, 176 of the 304 existing councils ( 58 per cent) had an administrative committee appointed to oversee them. This considerable number indicates the willingness of citizens to get involved in politics. Some proposed themselves as a candidate for their local administrative committee; others were invited to stand by the Portuguese Communist Party, the only political party existing at that time. As new parties were formed they too began to nominate candidates to the committees. The speed with which administrative committees were appointed demonstrates how rapidly and efficiently the central authorities complied with JSN instructions to replace local councillors. That said, the membership of only two administrative committees, those of Portalegre and Lisbon, were announced in August 1974; even at the height of the revolution, staff at the Interior Ministry insisted on taking their summer holidays.

Between 1974 and the first local elections on 12 December 1976, a total of 464 individuals were appointed to preside over the administrative committees, including nine women, 1.9 per cent of the total. Of the 277 vice-chairmen appointed, six (2.6 per cent) were women. A total of 92 women served as councillors on the administrative committees, 3.6 per cent of all councillors.

Over the transition period the town of Cascais saw five different administrative committees appointed, but it was a special case; generally there was a considerable degree of stability during the transition period. The administrative committees for 117 (38.5 per cent) of councils remained in operation unchanged throughout the transition period, and 169 (55.6 per cent) of committees had only one chairman throughout that time. 
The majority of administrative committee members came from groups that had formed 'clandestine and semi-legal opposition to the old regime' at the local level, particularly the Portuguese Democratic Movement, Movimento Democrático Português or MDP, an organisation linked to the Communist Party (Partido Comunista Português, or PCP). Francisco Sá Carneiro, Portugal's Social Democrat prime minister who was assassinated in 1980, declared that such groups had performed an 'assault on local authority', because during the revolutionary period (PREC) they not only challenged local government, but campaigned against the unions and the press as well. ${ }^{42}$ During the PREC the PCP was seen to infiltrate a 'considerable number of intermediate associations that facilitate the mobilisation and control of social interests: workers' commissions and factory committees, local unions and national workers' confederations, specialist professional associations, intellectual study groups, residents' committees, tenants' associations, local government, student groups and faculty councils, soldiers' organisations and non-communist organisations' ${ }^{43}$

In Portugal's northern districts the people were more likely to contest the choice of left-wing administrative committee members, leading to a greater number of changes of committee. In the south, where support for parties of the left was - and remains - much greater, the administrative committees went longer without change.

The elites forming local governments after the revolution were sociologically different from those they had replaced. For one, they were drawn from a wider range of occupations, and while 93 per cent of mayors during the New State were university graduates, only 229 chairmen of administrative committees, that is just 49.4 per cent, had university degrees and only 5.2 per cent had a technical qualification, such as technical engineer, solicitor, or agricultural technician.

Table 4 shows that during the 1974-1976 period, almost one third (32.1 per cent) of administrative council chairmen were 'specialists - intellectuals or scientists'. Just over 43 per cent of this group belonged to legal occupations such as lawyers, notaries, registrars and trainees, 25.9 per cent were medical doctors, 14.3 per cent were engineers, 4.8 per cent veterinarians and 4.1 per cent economists, with the remaining 8 per cent made up of four architects, four pharmacists, one sculptor, one geologist, one journalist, a mathematician and a musician. Of the nine chairwomen, three were teachers; a significantly higher proportion than among men. In total, 62 chairmen were teachers. There were no female merchants, administrators or technicians. Civil servants, a category that grew in importance over time, accounted for two out of the nine chairwomen (22.2 per cent) but for only 8.1 per cent of male chairmen. Military officers accounted for 2.6 per cent of the chairmen, or 3.5 per cent if the other military men - two militia officers, a merchant marine officer and a Republican National Guards officer - are included. 
In comparison with Table 1, Table 4 demonstrates the diversification of the occupations of those in local government during the transition period. During the PREC there was clear and intentional enlargement of the socio-economic group from which local elites were drawn. Committee members with new categories of occupation appear, with occupations that would previously have been unthinkable for members of the political elite. The fact that a fruit seller, workers from several industries and agricultural workers could aspire to political positions underlines how important interventionism was during the revolutionary phase, and how this encouraged the mobilisation of the population, 'awakening [them] to political participation'. ${ }^{44}$

There is also evidence that certain occupational groups, previously thought to have irreconcilable differences, were to be found on the same administrative committees. The chairman of Almada's administrative committee was, for example, a budget planner for a construction company, while the other six councillors were an office employee, a cork worker, an electrician, an employee of the arsenal at Alfeite, a lawyer and a bank employee. In Famalicão the chairman was an engineer while the councillors included a medical doctor, a primary school teacher, a merchant, a lawyer, a mechanic and an industry manager. Such diversity of occupations renders the classical sociological theories concerning the 'almost absolute separation of the political elite and the masses' obsolete; theories of the 'plural elite' were becoming increasingly applicable in Portugal. ${ }^{45}$

Among the chairmen of the administrative committees 14 men had retired and a further 2 were officers in the armed forces reserves; none of the chairwomen were retired. It was also possible to determine the age of 91 administrative committee chairmen on the day of their appointment. With an average age of 44, they were younger, on average, than the New State mayors (see Table 3).

\section{MAYORS DURING THE DEMOCRATIC REGIME, 1976-2013}

The continuity that was maintained during the transition from the military dictatorship of 1926-1933 to the stability of the New State regime was not repeated during the emergence of the Democratic regime. After 1976 there was an almost complete break from the administrative committees of 19741976. Of the members of the 304 councils and the 464 administrative committee chairmen appointed from 1974 to 1976 , only 16.6 per cent - drawn from 25.3 per cent of the councils - were elected under the Democratic regime. The continuity seen in 1937 can be explained by the fact that the Ministry of the Interior, which appointed administrative committees, also appointed the mayors; as a result, they sought not only the same individuals but also individuals with the same characteristics in both cases. With the transition to 
democracy there was greater discontinuity from the beginning; the electoral process changed the rules of the game from the outset. The plebiscite held in 1976 did not uphold either the local or central governments of the revolutionary period; the Socialist Party won 35 per cent of the parliamentary vote, while the Communist Party took just 14.4 per cent. In the local elections, the Socialist Party won 33 per cent of the votes and the majority of the municipalities, whereas the Communist Party, which had controlled most of the administrative committees during the transition period, took just 17.2 per cent of the votes.

From 1976 to 2013, a total of 1,273 people were elected to serve as mayor, holding office for an average of 8.4 years, or 2.3 terms (Tables 5 and 6), considerably longer than during the New State, suggesting that the office of mayor had become a much more attractive one. Indeed, under democracy long stays in office actually began to be seen as a problem, as there was a negative association between mayors serving consecutive terms in office and the people's willingness to participate in politics through public consultations or by making suggestions for improvements in public services. ${ }^{46}$ A connection was made between political longevity, a democratic deficit and corruption. The mayors who had served for many years became known as 'dinosaurs'; two mayors, one in Braga and one in Vila Nova de Poiares each served ten terms in office. In response to these issues a law was introduced in 2005, which limited each mayor to only three terms in office. As a result, when the first three consecutive terms ran out in 2013,63.2 per cent of all mayors were replaced in that year's elections. ${ }^{47}$

After more than half a century of candidates for local elections being appointed and not elected, in the first democratic local elections 'the parties became the almost exclusive channel for political mediation, and were consequently largely responsible for the mobilisation and participation of new social groups'. ${ }^{48}$

Those serving long terms in office furthered their careers by taking on roles in national, or even European, politics. This resulted in the professionalisation of political positions, something that had not existed during the New State. Under the democratic system those in politics were paid for their work, which allowed council members in less well-off districts, particularly the more rural ones, to dedicate themselves to their role, so also increasing professionalisation at the local government level. This meant that people from across a wider social spectrum could consider working in local government, and also that local politicians could specialise in particular areas of government or its administration.

Table 7 shows that mayors elected between 1976 and 2013 came from a range of occupations, with 'Specialists' dominating, although with a smaller proportion than was the case under the New State regime. 
TABLE 5

Length of terms in office: mayors 1976-2013

\begin{tabular}{lcr}
\hline \hline Length of term in years & Number of mayors & $\%$ \\
\hline $0-1$ & 28 & 2.08 \\
$1-2$ & 37 & 2.74 \\
$2-4$ & 499 & 37.02 \\
$4-8$ & 302 & 22.40 \\
More than 8 & 482 & 35.76 \\
Total terms served & 1348 & 100.00 \\
Mayors with 37 years in office (Braga and Vila Nova de Poiares) & 2 & 0.15 \\
Total number of individual mayors & 1273 & \\
Longest term of office (years) & 37 & \\
Average term of office (years) & 8.4 & \\
\hline
\end{tabular}

Source: STAPE Archive (Secretariado Técnico dos Assuntos para o Processo Eleitoral, Ministério da Administração Interna): microfilms with data on local elected representatives, 1976-1989; CDRom, 1993-1997; G. Archer ed., Caracterização das Mulheres Eleitas: Autarquias Locais 1997 (Lisbon, 2001); G. Archer and S. Tavares, Perfil do Autarca Caracterização dos Eleitos Locais 2001 (Lisbon, 2005); G. Archer, S. Costa and E. Rosário, Caracterização dos Eleitos para as Autarquias Locais - 1989, (Lisbon, 1993); G. Archer and S. Costa, Caracterização dos Eleitos Locais - Autárquicas 1993 (Lisbon, 1997); G. Archer, S. Tavares and S. Piteira, Caracterização dos Eleitos Locais - Autárquicas 1997 (Lisbon, 1998); National election committee, available at www.cne.pt

TABLE 6

Number of terms in office: mayors 1976-2013

\begin{tabular}{lcr}
\hline \hline Number of terms served & Number of mayors & $\%$ \\
\hline$<1$ (Failed to complete term) & 60 & 4.48 \\
1 & 494 & 36.92 \\
$>1$ and $<3$ & 510 & 38.12 \\
$>3$ and $<5$ & 211 & 15.77 \\
$>5$ & 63 & 4.71 \\
Greatest number of terms served (2 cases) & 10 & \\
Average number of terms served & 2.3 & \\
\hline
\end{tabular}

Source: See Table 5.

Under the Democratic regime a greater proportion of councillors were teachers, civil servants, intermediate-level technicians and bankers. Recruitment to the councils was almost exclusively through affiliation to a political party, and personal support for a candidate, or the services they could offer to 
TABLE 7

The occupations of mayors, 1976-2013

\begin{tabular}{lrr}
\hline \hline Occupations & Number & $\%$ \\
\hline Farmers & 19 & 1.57 \\
Bankers & 87 & 7.19 \\
Merchants & 33 & 2.73 \\
Entrepreneurs/Industrialists & 81 & 6.69 \\
Specialists - Intellectuals and Scientists & 311 & 25.70 \\
Civil Servants & 150 & 12.40 \\
Military Officers & 14 & 1.16 \\
Workers, Craftsmen and Machine Operators & 24 & 1.98 \\
Other Military (police officers and other military forces) & 2 & 0.17 \\
Priests & 5 & 0.41 \\
Administrative and Similar Personnel, Services and Salesmen & 74 & 6.12 \\
Teachers & 248 & 20.50 \\
Landowners & 13 & 1.07 \\
Senior Managers and Directors in Public Administration and Business & 47 & 3.88 \\
Technicians and Intermediate-level Professionals & 98 & 8.10 \\
Rural Workers & 4 & 0.33 \\
Total Occupations & 1210 & 100.00 \\
\hline \hline
\end{tabular}

Source: See Table 5.

their community, were important recruitment criteria. The new mayors were mainly service providers, in contrast to the job providers their predecessors had been.

Table 8 shows that, post-1976, a greater proportion of mayors, 27 per cent, had not attended university, compared to just 7.1 per cent under the New State. The average age of democratically elected mayors was 43.3, lower than the 45.2 of mayors appointed between 1937 and 1974. The mayors elected in 1976 were just 42.1 on average. In 2013, when almost two thirds of the mayors were replaced, the average age of mayors at the end of their terms was 63.5 years. The 2013 election not only renewed the body of mayors, it also rejuvenated them (the mayors elected in 2013 averaged 49 years), although as a group their sociological and political profiles were not very different from those of their predecessors.

Many of the mayors and councillors had retired from their occupation; of the 14 military officers in Table 7, 12 were retired. In the district capitals and other major towns it was possible to pursue a career in politics and aspire to the role of civil governor, member of parliament or even a position in central government, in smaller towns it was not uncommon for people who had retired from their occupation to return to their home town and enter the local 
TABLE 8

The educational qualifications of mayors, 1976-2013

\begin{tabular}{lrr}
\hline \hline Level of education attained & Number of mayors & $\%$ \\
\hline Primary school & 17 & 1.94 \\
Preparatory cycle & 7 & 0.80 \\
Ninth year of schooling & 17 & 1.94 \\
Technical course & 109 & 12.43 \\
Secondary school & 39 & 4.45 \\
Primary teacher & 48 & 5.47 \\
Baccalaureate & 10 & 1.14 \\
Higher studies & 69 & 7.87 \\
Undergraduate degree & 499 & 56.90 \\
Postgraduate degree & 36 & 4.10 \\
Master's & 23 & 2.62 \\
PhD & 3 & 0.34 \\
Total & 877 & 100.00 \\
\hline \hline
\end{tabular}

Source: See Table 5.

administration. However, there were also ministers and members of parliament who ran for mayor.

In short, the social and demographic profile of Portuguese local politicians in recent years reflects the international trend of the 'three Ms': they are generally male, middle-aged and middle-class, as well as, 'high in professional status and well-educated'. ${ }^{49}$ This description also fits the members of parliament and the ministers and presidents who hold national office, although there tend to be rather more 'specialists' among the latter two groups, rather than the mayors. ${ }^{50}$

\section{TRANSITION BETWEEN REGIMES AND POLITICAL MOBILITY}

The political mobility of mayors, civil governors and groups in government was very low during the New State; very few mayors were also civil governors, members of parliament, or ministers. Furthermore, the transition of local political elites between regimes was almost zero. Only 1.1 per cent of mayors elected after 1976 had served as a mayor before 1974; more than 98 per cent of mayors who served before 1974 had no role in the political life of the new, Democratic regime. None of the civil governors appointed before 1974 were reappointed after the Revolution. One was elected, but as a mayor, in 1985, and a further two were elected to parliament and two more were elected as presidents of municipal assemblies in the same year. Five of the civil governors 
appointed after 1974 had held office during the New State: two as members of the Corporate Chamber, the lower house of Portugal's parliament, one as a mayor and two as deputy mayors. Very few pre-1974 mayors were elected to continue in this role after 1976, in fact only 13 made this transition.

A total of 12.3 per cent of mayors who were elected between 1976 and 2005 had previously been members of the Portuguese parliament and a further 1.1 per cent had been members of the European parliament, either before or during their time in local government. Movement was not just from local government to parliament; a number of members of parliament were elected as mayors. Previous political experience undoubtedly counted in the local elections, and each candidate took advantage of political opportunities, such as those created by a change of government or when a minister, secretary of state or a member of parliament lost their position. When this happened, such candidates would be placed by their parties in first position on the local electoral lists, in order to make them eligible for appointment as mayor. There was also mobility between political positions and leading roles in public companies. Some Portuguese politicians spent time as the chairman of a football club, a trend also seen in the South of France.

\section{WOMEN'S PARTICIPATION IN LOCAL POLITICS}

Even today women are underrepresented in Portuguese politics, but the 1974 revolution drew women into politics, particularly at local government level, where they had never previously occupied top positions. Although three councils had women councillors under the New State, not one woman served as mayor under that regime.

Of the administrative committees appointed in 1974, nine were headed by women. Between 1976 and 2005 a total of 37 women were elected as mayors, or 2.8 per cent of all mayors elected in this period. Up to 2013 the number rose and women currently occupy 7 per cent of the mayor positions. Nevertheless, this number is far from the 33 per cent female members of parliament elected in 2015 .

Given the small number of women mayors, any characterisation of this group is necessarily limited, almost personal. Be that as it may, this group of women were better educated than their male peers, a feature that chimes with the wider demographic reality in Portugal. In 1961, out of every hundred students who obtained a university degree, only 24.5 were women, but by 1995 this figure had risen to 62.9 .51 In 2011, 22.9 per cent of the Portuguese population between 25 and 64 years of age had a university degree: 18.4 per cent of men and 26.9 per cent of women. ${ }^{52}$

Over 55 per cent of the women who headed administrative committees had university degrees compared to 49.2 per cent of the men. Among women mayors elected between 1976 and 2005, 58 per cent had a university 
TABLE 9

Council mayors by gender, 1976-2013

\begin{tabular}{lccccc}
\hline \hline Elections: & Nof Women elected: & $\%$ & Nof Men elected: & $\%$ & Total elected: \\
\hline 1976 & 5 & 1.6 & 299 & 98.4 & 304 \\
1979 & 4 & 1.3 & 301 & 98.7 & 305 \\
1982 & 6 & 2.0 & 299 & 98.0 & 305 \\
1985 & 4 & 1.3 & 301 & 98.7 & 305 \\
1989 & 7 & 2.3 & 298 & 97.7 & 305 \\
1993 & 5 & 1.6 & 300 & 98.4 & 305 \\
1997 & 12 & 3.9 & 293 & 96.1 & 305 \\
2001 & 16 & 5.2 & 292 & 94.8 & 308 \\
2005 & 19 & 6.2 & 289 & 93.8 & 308 \\
2009 & 23 & 7.5 & 285 & 92.5 & 308 \\
2013 & 22 & 7.1 & 286 & 92.9 & 308 \\
Mean & 11 & 3.6 & 295 & 96.4 & 100 \\
\hline \hline
\end{tabular}

Source: See Table 5.

qualification, but this was true of only 43 per cent of their male colleagues. Some 55.5 per cent of administrative committee chairwomen were teachers, scientists or intellectuals: three were secondary school teachers and two held law degrees, one being a public registrar, the other a notary. Only 45.3 per cent of male mayors were in the same status group. During the Democratic period, the percentage of female mayors in this group grew to 59 per cent, while among male mayors it fell to 44 per cent. Women mayors were geographically concentrated in the coastal districts; 71 per cent were found there, with the greatest number in the districts of Lisbon, Setúbal and Aveiro, reflecting the regional pattern of female economic activity.

Female mayors were on average 44.3 years old when they took office, somewhat older than the average for all mayors of 43.4. The women held office for an average of 7.3 years, slightly less than the 8.4 year overall figure, and most were incomers to the area they governed, 50 per cent coming from another government district, 22.7 per cent from another council area within the same district, and only 27.3 per cent sitting on their native council. Ninety per cent of the female mayors resided within the area governed by the council they headed, and a further 7 per cent lived within the same government district. When it came to political parties, 38.7 per cent of women mayors represented the Social Democratic Party (Partido Social Democrata), 29 per cent the Socialist Party (Partido Socialista) and 29 per cent the Communist Party and its coalition partners. Thus, in combination the parties on the left of the political spectrum accounted for 58 per cent of all women mayors. ${ }^{53}$ 


\section{CONCLUSIONS}

Table 10 provides a résumé of the characteristics of the different sets of local government officials, and how these evolved over the events surrounding the Revolution which took place in Portugal in 1974, heralding the third wave of democratisations to take place in southern Europe. ${ }^{54}$ Most studies of the political elites in the countries tend to concentrate on ministers and members of parliament; ${ }^{55}$ few consider those in local government. It is therefore difficult to undertake a comparative study, unless the comparison is with northern and eastern Europe, where local political elites have contributed to the success of the democratisation process. ${ }^{56}$ It is clear that the different paths taken to democracy produced populations with different capabilities of selforganisation. In Portugal, the Carnation Revolution and its aftermath produced a population who were much more willing to participate in local government than was the case in Spain, for example. ${ }^{57}$

In Portugal, the elite politicians of the New State were almost entirely replaced after the Revolution; coming from a much more diverse range of occupations, the new elite brought new skills with them. However, specialists - intellectuals and scientists with high levels of education - continued to dominate local and national government, as in the rest of Europe, where 'despite differences over time and between political systems the disproportional recruitment of certain social groups with distinctive characteristics into the (local) political elite is one of the most replicated and perpetual findings'. 58

According to Ruivo, democracy was a motor of change. The occupations of the newly-elected local officials after the Revolution in Portugal reveal that they were predominantly middle-class professionals, who 'tend(ed) to be people with a different way of relating to both politics and with the community'.59 Was this really a consequence of the transition to democracy? Or has the local political elite been undergoing a slow evolution during the last four decades as a result of several other factors, such as European integration, new methods of local government finance or even demographic, economic and social changes? The social re-composition of councils occurred when the people took power into their own hands, thus inflicting significant changes on the social groups that had traditionally exercised power in local government. At the 1976 elections, Portugal's voters chose not to endorse the Revolution and its elites. The process of stabilisation that followed is summed up by Philippe Schmitter's description of the Portuguese transition to democracy: the country went 'from the fiery rapture of a revolutionary transition to the satisfactory (although prosaic) routine of a consolidated democracy'. ${ }^{60}$

Our earlier research on Alentejo demonstrated that in that region of the south of Portugal local elites remained the same for over two hundred years, and through three regime-changing revolutions, until the 1974 Revolution 
TABLE 10

Summary descriptive statistics: Portuguese mayors 1937-1974, chairs of administrative committees 1974-1976, and mayors 1976-2013

\begin{tabular}{lccc}
\hline \hline & $\begin{array}{c}\text { New State, } \\
1937-1974\end{array}$ & $\begin{array}{c}\text { Chairs of administrative } \\
\text { committees, 1974-1976 }\end{array}$ & $\begin{array}{c}\text { Democratic regime, } \\
1976-2013\end{array}$ \\
\hline $\begin{array}{l}\text { Average age at appointment } \\
\text { or election }\end{array}$ & 45.2 & 44 & 43.3 \\
$\begin{array}{l}\text { Qualifications: university } \\
\text { degrees }\end{array}$ & $92.9 \%$ & $49.4 \%$ & $73.0 \%$ \\
$\begin{array}{l}\text { Professions: specialists, } \\
\text { intellectuals and scientists }\end{array}$ & $34.7 \%$ & $32.1 \%$ & $25.7 \%$ \\
$\begin{array}{l}\text { Professions: armed forces } \\
\text { officers }\end{array}$ & $22.0 \%$ & $2.6 \%$ & $1.2 \%$ \\
$\begin{array}{l}\text { Professions: teachers } \\
\text { Professions: landowners }\end{array}$ & $14.0 \%$ & $13.4 \%$ & \\
Average length of term & $6.9 \%$ & $4.5 \%$ & $20.5 \%$ \\
Women & 5.3 & 1.5 & $1.1 \%$ \\
\hline \hline
\end{tabular}

Source: see Tables 1 and 5.

replaced them totally. ${ }^{61}$ In present-day Alentejo, landowners, the traditional political elites, no longer stand for local elections, and economic power is no longer a way of ensuring local political leadership. New occupations have emerged to take up political careers; landowners are now completely and deliberately absent from local politics. When their land was seized as part of the 1975 agrarian reform, the landowners moved away from their home districts to pursue other professional interests. If and when they returned, they were not interested in taking political power; their professional activities, whether in agriculture or not, were increasingly time consuming and provided them with incomes far more appealing than a mayor's salary. Currently when elections are held in Portugal the Communist Party continues to win in some municipalities in the Alentejo region, thanks to the consolidation of communist sympathies that have developed over the last century.

Elsewhere in Portugal other criteria have emerged as key to political recruitment; party affiliation, the ability to manage regional interests, recruitment strategies based on competitive skills, and the ownership of social capital at the local level. Candidates for local government now have to demonstrate that they are willing to attract investment in local industry, services and job creation in order to lure voters, with programmes meant to promote new families' relocation to their municipalities, create jobs and fight depopulation proving particularly popular. 


\section{ACKNOWLEDGEMENTS}

This research was funded by a postdoctoral grant from the Foundation for Science and Technology, Ref. BPD/92956/2013.

\section{ENDNOTES}

1 F. Rosas, Salazar e o Poder: A Arte de Saber Durar (Lisbon, 2013).

2 A. Pinto, 'Introduction: repression and cooptation in mass dictatorship', in P. Corner and J. Lim eds., The Palgrave handbook of mass dictatorship (London, 2016), 101.

3 A. Coelho, Comunas ou Concelhos (Lisbon, 1986); C. Oliveira ed., História dos Municípios e do Poder Local (dos finais da Idade Média à União Europeia (Lisbon, 1996).

$4 \mathrm{~J}$. Mendes, 'O contributo da biografia para o estudo das elites locais: alguns exemplos', Análise Social 26, 116-17 (1992), 359.

5 M. Almeida, O Poder Local do Estado Novo à Democracia: Presidentes de Câmara e Governadores Civis, 1936-2012 (Lisbon, 2013); M. Almeida, Dicionário biográfico do poder local em Portugal, 1936-2013 (Lisbon, 2014).

6 R. Inglehart and P. Norris, Rising tide: gender equality and cultural change around the world (Cambridge, 2003), 91.

7 M. Almeida, 'Fontes e metodologia para o estudo das elites locais em Portugal no século XX', Análise Social 43, 188 (2008), 627-45.

8 F. Ruivo, 'Local e Política em Portugal: o Poder Local na Mediação entre o Centro e a Periferia', Revista Crítica de Ciências Sociais 30 (1990), 77.

9 A. Vargas, 'Mulheres na Assembleia Nacional (1933-1974)', Eleições: Revista de Assuntos Eleitorais 6 (2000), 43- 67.

10 J. Viegas and S. Faria, As mulheres na política (Lisbon, 1999), 19.

11 Almeida, O Poder Local do Estado Novo à Democracia, 28.

12 P. Bourdieu, O Poder Simbólico (Lisbon, 1989), 136-7.

13 Government Decree No. 236/74, 3 June 1974.

$14 \mathrm{H}$. Wollmann, 'Local government reforms in Great Britain, Sweden, Germany and France: between multi-function and single-purpose organisations', Local Government Studies 30, 4 (2004), 641.

15 G. Allegretti and N. Dias, 'Participação e cidadania', in L. de Sousa, A. F. Tavares, N. Ferreira da Cruz and S. Jorge eds., A Reforma do Poder Local em Debate (Lisbon, 2015), 185-91.

16 M. Reiser and E. Holtmann eds., Farewell to the party model? Independent local lists in east and west European countries (Wiesbaden, 2008).

17 M. Almeida, 'Independents and citizen's groups in Portuguese municipalities', in Reiser and Holtmann eds., Farewell to the party model?, 233-51.

18 M. Almeida, 'Party politics in Portugal: municipalities and central government', European Societies 10, 3 (2008), 357-78.

19 M. Almeida, Grupos de cidadãos nas autarquias portuguesas: contributo para a prática da cidadania e para a qualidade da democracia? (Lisbon, 2016).

20 A. Pinto, 'O império do professor: Salazar e a elite ministerial do Estado Novo (1933-1945)', Análise Social 35, 157 (2001), 1055-76.

21 R. Ramos, 'O Estado Novo perante os poderes periféricos: o governo de Assis Gonçalves em Vila Real (1934-39)', Análise Social 22, 90 (1986), 109-35; M. Lucena, Evolução do Sistema Corporativo Português, 2 vols. (Lisbon, 1976); M. Almeida, Família e Poder no Alentejo (Elites de Avis: 1886- 1941) (Lisbon, 1997).

22 Lucena, Evolução do Sistema Corporativo. 
23 Bourdieu, O Poder Simbólico; Almeida, O Poder Local do Estado Novo à Democracia, 134.

24 Almeida, Dicionário biográfico do poder local; M. Rodrigues, Saldanhas: Condes e Marqueses de Rio Maior (Santarém, 2014).

25 Almeida, Dicionário biográfico do poder local.

26 R. Carvalho and T. Fernandes, 'A elite política do marcelismo: ministros, secretários / subsecretários de Estado e deputados (1968-1974)', in A. Pinto and A. Freire eds., Elites, Sociedade e Mudança Política (Oeiras, 2003), 72.

27 A. Barreto ed., A Situação Social em Portugal 1960-1999, 2 vols. (Lisbon, 2000), ii, 103; www.ine.pt.

28 Carvalho and Fernandes, 'A elite política do marcelismo', 68; J. Castilho, 'A elite parlamentar do marcelismo (1965-1974)', in Pinto and Freire eds., Elites, Sociedade e Mudança Política, 55.

29 D. Cerezales, O Poder Caiu na Rua: Crises de Estado e Acções Colectivas na Revolução Portuguesa 1974-1975 (Lisbon, 2003).

30 N. Bermeo, The Revolution within the Revolution: workers' control in rural Portugal (Princeton, NJ, 1986).

31 M. Almeida, A Revolução no Alentejo: Memória e Trauma da Reforma Agrária em Avis (Lisbon, 2006).

32 M. Almeida, 'Memory and trauma of the Portuguese Agrarian Reform: a case study', Portuguese Journal of Social Science 6, 2 (2007), 63-76.

33 J. Ferreira, Portugal em Transe (1974-1985) (Lisbon, 1993), 351.

34 J. Cutileiro, A Portuguese Rural Society (Oxford, 1971).

35 M. Almeida and C. Martins, 'Alugador de máquinas', in Nuno Luís Madureira ed., História do Trabalho e das Ocupações, 3 vols. (Oeiras, 2002), iii, 285-8.

36 V. Carvalho, O Fracasso de um processo: A Reforma Agrária no Alentejo (Lisbon, 1977); J. Garin, Reforma Agrária: Seara de Ódio (Lisbon, 1977); J. Maltez, A estratégia do PCP na Reforma Agrária (1974-1976): Relatório Síntese (Lisbon, 1989).

37 M. Lucena, 'A revolução portuguesa: do desmantelamento da organização corporativa ao duvidoso fim do corporativismo', Análise Social 13, 51 (1977), 567.

38 Almeida, A Revolução no Alentejo.

39 M. Almeida, Memórias Alentejanas do Século XX (Cascais, 2010).

40 Almeida, A Revolução no Alentejo; Almeida, O Poder Local do Estado Novo à Democracia.

41 R. Santos, 'Senhores da terra, senhores da vila: elites e poderes locais em Mértola no século XVIII', Análise Social 28, 121 (1993), 345-69.

42 F. Sá Carneiro, Por uma social-democracia portuguesa (Lisbon, 1975).

43 P. Schmitter, Portugal: do autoritarismo à democracia (Lisbon, 1999).

44 I. Guerra, 'Poder local: reprodução ou inovação?', Sociologia - Problemas e Práticas 1 (1986), 58; A. Fernandes, 'Poder Local e Democracia', Sociologia: Revista da Faculdade de Letras da Universidade do Porto 1, 2 (1992), 30.

45 A. Freire ed., Recrutamento Parlamentar: os Deputados Portugueses da Constituinte à VIII Legislatura (Lisbon, 2001), 10-11.

46 A. Tavares and M. Rodrigues, 'The supply of political and administrative instruments of participation: an empirical analysis of local government choices', Revista del CLAD Reforma y Democracia 56 (2013), 141-72.

47 M. Almeida, 'Longevidade nas autarquias e responsabilização dos autarcas: questões pendentes no poder local em Portugal', Mátria XXI 4 (2015), 119-38.

48 M. Mendes, 'As Elites Políticas num Concelho da Área Metropolitana do Porto', Sociologia Problemas e Práticas 14 (1993), 178. 
49 S. Eldersveld, L. Stromberg and W. Derksen, Local elites in Western democracies: a comparative analysis of urban political leaders in the U.S., Sweden and the Netherlands (Boulder, CO, 1995).

50 A. Pinto ed., Os Presidentes da República Portuguesa (Lisbon, 2001); A. Pinto and P. Almeida, 'Portuguese ministers, 1851-1999: social background and paths to power', South European Society and Politics 7, 2 (2002), 5-40.

51 Barreto ed., A Situação Social em Portugal, ii, 108.

52 See www.ine.pt

53 M. Almeida, 'Women in Portuguese politics', Portuguese Journal of Social Science 8, 2 (2009), 177-89. See also P. Nunes, 'Participação das mulheres na politica autárquica em Portugal nos últimos vinte cinco anos (1982-2005): especial relevo para as mulheres eleitas apuradas para a presidência de órgãos', Revista Enfoques 6, 9 (2008), 11-34.

54 L. Diamond and M. Plattner eds., Consolidating third wave democracies (Baltimore, 1997).

55 A. Pinto, P. Almeida and N. Bermeo eds., Who governs southern Europe? Regime change and ministerial recruitment, 1850-2000 (London, 2003).

56 S. Szucs and L. Stromberg eds., Local elites, political capital and democratic development: governing leaders in seven European countries (Wiesbaden, 2006).

57 T. Fernandes, 'Rethinking pathways to democracy: civil society in Portugal and Spain, 1960s2000s', Democratization 22 (2015), 1074-104.

58 K. Steyvers and H. Reynaert, "From the few are chosen the few ...": on the social background of European mayors', in H. Back, H. Heinelt and A. Magnier eds., The European mayor: political leaders in the changing context of local democracy (Wiesbaden, 2006), 43.

59 Ruivo, 'Local e Política em Portugal', 76.

60 Schmitter, Portugal: do autoritarismo à democracia, 19.

$61 \mathrm{M}$. Almeida, 'Landlords, tenants and agrarian reform: local elites and regime transitions in Avis, Portugal, 1778-2011', Rural History 24, 2 (2013), 127-42.

\section{FRENCH AND GERMAN ABSTRACTS}

La révolution dans l'administration locale: les maires au Portugal avant et après 1974

Au Portugal, en 1974, la Révolution des œillets, lancée par l'armée, reçut un large soutien populaire. Ce sont les officiers, des capitaines principalement, qui ont commencé la révolution, et les politiciens ont pris la relève. Bien qu'il s'agisse d'une révolution initiée 'par le haut', des gens ordinaires prirent le contrôle au niveau de l'administration locale. Dans cet article, nous étudions les élites locales avant les événements de 1974, qui furent les nouveaux venus qui émergèrent aux responsabilités durant la période de transition et enfin qui détenait le pouvoir local par la suite. Nous comparons ainsi les élites locales au Portugal pendant la dictature de Salazar avec celles du régime démocratique, en utilisant une base de données de 6000 entrées contenant des détails sur 3102 maires et adjoints au maire et 402 administrateurs civils qui ont occupé leurs fonctions entre 1936 et 2013. Nos principales conclusions concernent les élites qui avaient régné sous Salazar: pendant la période de transition, leurs représentants furent presque tous complètement remplacés. Un nouveau groupe, issu de différentes professions et milieux sociaux, prit alors en mains les rênes de l'administration locale. La Révolution des EEillets a donc produit une population désireuse de participer à l'ordre nouveau, et de prendre des responsabilités au niveau local. Mais 
ces personnes n'ont pas toujours conservé leurs sièges avec les premières élections démocratiques.

Die Revolution der Lokalverwaltung: Bürgermeister in Portugal vor und nach 1974

Die 1974 durch das Militär ausgelöste portugiesische Nelkenrevolution wurde vom Volk massiv unterstützt. Armeeoffiziere, meist im Rang eines Hauptmanns, setzten die Revolution in Gang, aber dann übernahmen die Politiker das Ruder. Während es sich hauptsächlich um eine Revolution, von oben nach unten' handelte, übernahmen auf der Ebene der Lokalverwaltung einfache Leute die Kontrolle. In diesem Beitrag untersuchen wir diejenigen, die zur lokalen Elite gehörten, und zwar vor der Revolution, während der anschließenden Übergangsphase, und in der Zeit danach. Wir vergleichen die lokalen Eliten in Portugal während der Diktatur unter Salazar mit denjenigen unter der demokratischen Regierung und ziehen dafür eine Datenbank mit rund 6.000 Einträgen heran, die Einzelheiten über 3.102 Bürgermeister und stellvertretende Bürgermeister und 402 Zivilgouverneure enthält, die zwischen 1936 und 2013 im Amt waren. Unsere wichtigsten Ergebnisse lauten, dass die Elite, die unter Salazar geherrscht hatte, während der Übergangsphase fast vollständig ausgewechselt wurde. Eine neue Gruppe von anderer beruflicher und sozialer Herkunft übernahm die Zügel der Lokalverwaltung. Aus der Revolution ging eine Bevölkerung hervor, die bereit war, an der neuen politischen Ordnung teilzuhaben und Aufgaben innerhalb der Lokalverwaltung zu übernehmen, aber nach den ersten demokratischen Wahlen behielten sie nicht immer ihre Sitze. 